\title{
Research on the Mixed Teaching Reform of Higher Vocational Colleges against the Background of Work-Study Combination
}

\author{
Zhu Biao \\ Chongqing Technology \& Business Institute \\ Hechuan, Chongqing 401520
}

\begin{abstract}
This research is aimed to explore the mixed teaching reform approach for colleges under the background of work-study combination. On the basis of analyzing the problems existed in the mixed teaching of higher vocational colleges of our country, it defines the work-study combination mixed teaching connotation, puts forward the countermeasures and suggestions for six aspects, including school-running system, talent cultivation mode, mixed teaching reform, double-qualified teacher group construction, innovation and entrepreneurship platform construction and system guarantee.
\end{abstract}

Keywords-Work-study combination; Mixed teaching; Teaching reform

\section{INTRODUCTION}

German higher vocational education taking "dual system" mode as the main characteristic has obtained the support from the government, the industry, and the education research aspects, and it has become the development road for our country to study German "dual system", and take it as reference, so as to build vocational education system with Chinese characteristics, and explore the work-study combination in vocational education of our country [1]. The education thought of "work-study combination" is the heated topic for the vocational education theory research and practice field in our country. Chinese higher vocational education has entered into "post-demonstration" "post-backbone" period; in the current period, the core task for higher vocational colleges is connotation construction, "work-study combination" teaching mode reform is still the key point for the course construction in higher vocational colleges [2]. Along with the development of education information technology in the recent years, the wide popularity of MOOC in vocational education takes the mixed teaching mode reform as an opportunity, and becomes the key for changing talent cultivation mode under the background of work-study combination.

This paper is the research achievement for the Development Plan Project of Chongqing Technology \& Business Institute "the Economic Management Type of Productive Training Base Construction in Our Country Docks with the Strategic Research and Practice of Chongqing Industry" (Project No.: FG2016B02)

\section{Problems EXISTING IN THE Mixed Teaching OF HigHER VOCATIONAL COLLEGE}

Vocational colleges should energetically promote the cultivation mode of school-enterprise cooperation, and workstudy cultivation mode. The teaching resource construction and development under the talent cultivation mode of work-study combination will be beneficial to the implementation of mixed teaching, and higher vocational colleges should integrate enterprise talent demand in teaching practice, and integrate enterprise management mode in mixed teaching [3].

\section{A. School-enterprise Cooperation Lacking in Benign interaction}

School-enterprise cooperation is the core for the workstudy combination talent cultivation mode. School-enterprise cooperation lacks in benign interaction; on one hand, enterprise' awareness for entering into school for talent cultivation is insufficient, and the enthusiasm isn't high, and they hold that they are employers and can select talents, and the cultivation of talents is the responsibility of schools; they don't want to pre-pose training in the learning period of students. On the other hand, the on-campus training bases constructed by higher vocational colleges lack in enterprise participation, and have no external productivity or serviceability. Higher vocational colleges will sign school-enterprise cooperation agreement with enterprises, and since colleges cannot bring profits to enterprises, it is also hard for enterprises to input resources, to guide the study of students, which has caused the difficulty in performing the school-enterprise cooperation agreement, and finally, it will be put aside and neglected, and become the material for inspection and evaluation [3]

\section{B. Lack for Talent Cultivation Mode cognition}

Currently, the most common mode for the work-study combination of higher vocational colleges is to let students find enterprises for post practice in the last semester. Higher vocational colleges cannot fast respond to the work-study combination mixed teaching, and student management mode reform; besides, it is hard for teachers to go deep into enterprises and the basic level to guide the internship of students, and they don't want to do it, either. When formulating talent cultivation objective, many schools and majors are way 
too wide, with no accurate enough position. Partial higher vocational colleges' cognition on "school-enterprise cooperation and work-study combination" is merely kept at the thought of letting students work as intern in the society and enterprises or use their own winter and summer vacation as well as extracurricular time to take on a part-time job in enterprises. It is hard to reflect the concept of work-study combination in talent cultivation scheme, course system, and professional course.

\section{Course System is Hard to Reflect the Requirements of Professional Posts (Groups)}

Currently, the course system in various higher vocational colleges can be basically divided into theoretical teaching system and practical teaching system, with serious discipline teaching system trace, and the course setup cannot reflect the work-study combination talent cultivation mode. For instance, the higher vocational industrial and commercial enterprise management is subject more influence of the traditional discipline teaching system, and with respect to contents about "Fundamentals of Management", "Marketing", "Fundamentals of Accounting" and other courses, there is few linkage between theory and actual work, and although higher vocational colleges pay attention to practical teaching, when formulating talent cultivation scheme, the proportion of practical teaching in some course teaching plans is still very big, but due to the restriction of conditions about the teachers, on-campus and offcampus practical bases, textbooks, etc. can often become formalistic, it is hard to form practical course system under the background of work-study combination, and reflect the demand of professional posts (groups) for students, and the teaching effect isn't obvious [4].

\section{Deficient Mixed Teaching resources}

Firstly, mixed teaching requires lots of texts, animations, videos, audios, textbooks, references and other media forms of online teaching resources, and this has caused the increase of difficulties in constructing work-study combination mixed teaching resources. The existing online resources cannot meet the teaching demand. Currently, the proportion for online courses of general knowledge, life, interest, and certificate training is relatively big, and excellent professional online courses are still very scarce. The current professional online courses are not entirely satisfactory in discipline distribution and quality. Some courses are merely the moving of offline college courses to online courses, failing to conduct the reconstitution of teaching contents, and forms, etc. as per the online teaching conditions [5].

Secondly, while constructing online teaching resources, most part of higher vocational colleges focus on the construction of teaching resources inside the school, and lack in docking with the professional posts (groups) of enterprises and industries; meanwhile, since the teaching reform participation degree and understanding of enterprises and industries are insufficient, even if enterprises have qualified teaching resources, it is hard to apply them in courses [6].

Thirdly, the compilation of textbook, and the courseware making cannot meet the working process, with weak applicability, and partial textbooks merely change the former chapters into projects, with openings in the project linkage, and the linkage among courses cannot reflect the demand of post (group).

\section{E. In Lack of "Double-qualified" Teachers, and Practical capacity}

In the implementation process of work-study combination courses, it requires to be carried out by teachers through focusing on enterprise production, and service process, with high requirements for the teaching, production, $R \& D$, organization design, and communication capacity of teachers. It adopts mixed teaching, and requires the teachers to develop and design the learning resources, scientifically organize teaching activities, and effectively guide the learning process of students [6]. Most teachers of higher vocational colleges are originated from schools and then worked in schools, with no first-line production and service experience in enterprises; although they have the opportunity to receive training in cooperated enterprises, it is very hard to ensure the training time under heavy teaching tasks, and it can be hard for young teachers to skillfully master practice skills. For teachers with more working years, along with the constantly developed new technologies and techniques, the practical skills of teachers cannot satisfy the requirements of post (group) professional capacity. Partial higher vocational colleges will hire enterprise engineering technology personnel, business backbone, manager and other personnel as full-time practice teachers, but due to the school expenditures and enterprise operation requirements, they cannot provide guidance to students all the time [7].

\section{F. Traditional Teaching Management Mechanism Cannot Adapt to the New Situation}

The campus network construction and popularity in higher vocational colleges, the networked teaching platform, the scaled network classroom, multimedia teaching environment, popularity of mobile smart terminal, convenient and efficient instant messenger, etc. have changed the teaching era, teaching means and teaching methods in higher vocational colleges. For instance, teachers can conveniently communicate with students through email, QQ, WeChat, etc., and even use live broadcast, WeChat, etc. to reinforce the interaction with students; the popularity of campus network and the decrease of $4 \mathrm{G}$ expenses can let students study whenever and wherever possible. The traditional teaching management system has become increasingly unsuitable for implementing mixed teaching mode under the background of work-study combination.

\section{CONNOTATION OF WORK-STUDY COMBINATION MiXED TEACHING MODE}

Just like German "dual system" mode, American "cooperation education" mode, British "sandwich education" mode, Australian "technology and continuous education" mode, and Canadian "capacity-based education" mode, the workstudy combination also emphasizes on the importance of "work" and "study" combination. For instance, German "dual system" has sound legal system, sound supporting measures, wide enterprise participation, and outstanding leading function; adheres to "student-based", emphasizes on teaching students in 
accordance of their aptitudes, possesses strong national identification, wide public recognition and other characteristics. When studying "dual system" vocational education mode, higher vocational colleges should change their thoughts, and correctly understand the connotation of work-study combination. Work-study combination requires the macroscopic education system of the government, and this is reflected in schools as talent cultivation mode, and penetrated in course system and teaching mode [1].

Under the horizon of work-study combination, the so-called mixed teaching refers to the diversified teaching mode constituted through utilizing digital or networked study and classroom teaching or enterprise practice and training. It is requested to carry out mixed teaching mode reform and practice, fully utilize different education environments and resources of schools, enterprises, industries, and government, organically combine the school education mainly focused on course teaching and the currently popular online education, the off-campus work that can directly obtain actual experience as well as the productive practice inside the campus, and let it run through the cultivation process of students' comprehensive quality, and vocational capacity training.

The "work" mentioned in the work-study combination not only refers to the actual work, it can be reflected in "workstudy alternation, task driving, project orientation, and post practice", etc. With respect to the teaching objective, the workstudy combination mixed teaching focuses on cultivating the students' post professional capacity, but it also includes the requirements for "knowledge".

With respect to the implementation of mixed teaching under the background of work-study combination, from the perspective of the teaching subject, students have dual identities, i.e., "the educator", and "the professional", and then participate in the theoretical knowledge study of schools and enterprises, the social practice activities and the post practice and training, etc. as per the professional training requirements. From the perspective of the teaching mode, it has combined classroom study, online study, and actual work, with diversified teaching contents, methods, time and place, and it requests flexible teaching management, and elastic learning system; from the perspective of the teaching process, teachers adopts flexible and diversified teaching modes; in MOOC era, mixed teaching application is extremely important. Students should pass through the dual process of "study" and "work". In the implementation process, characteristics such as "student subject", "teachers leading", and "enterprise participation" can be reflected. From the perspective of learning modes, it is requested to receive skill training in production post, complete field study, etc. through online network, and learn by doing; from the perspective of the evaluation method, school teachers and enterprise masters should implement joint guidance, and jointly participate in the completion.
IV. MiXed TEACHING REFORM MEASURES FOR HighER VOCATIONAL COLLEGES UNDER THE BACKGROUND OF WORKSTUDY COMBINATION

\section{A. Innovate School-running System, and Establish Government-industry-enterprise-school Cooperation Council}

Adopt stockholding system and other modes to innovate school-running mechanism. Vocational colleges should fully consider the actual demands of their own development, gather strength in industry, enterprises, social organization, individual, etc. to run schools, and explore stockholding system property right system reform of vocational colleges. Vocational colleges should rely on enterprises, serve the industry, and conduct active communication with enterprises considering professional construction, course system, sharing mechanism, training base construction, talent cultivation scheme and other aspects, sign school-enterprise cooperation agreement, realize resource sharing, and serve regional economic development.

Establish

government-industry-enterprise-school cooperation council. The government should formulate policies to encourage schools and enterprises to cooperate in running schools or establishing enterprises, implement policy guidance, erect platform, promote the in-depth cooperation of schools and enterprises, and for enterprises supporting work-study combination, it is requested to permit certain incline in tax preference, fund support, and qualification evaluation. The indepth cooperation of schools and enterprises requests the government to erect and expand channels for enterprises and schools, solve the lack in rights and obligations as well as the risk issues, and provide mechanism guarantee. Meanwhile, schools should actively search for, and expand channel service enterprises and government, establish government-industryenterprise-school cooperation platform and the governmentindustry-enterprise-school cooperation council, so as to tamp the work-study combination mixed teaching basis.

\section{B. Highlight Professional Characteristics, and Build Characteristic Work-study Combination Talent cultivation mode}

Different specialties in higher vocational colleges can master the internal contact of "work" and "study" as per their own industrial, school backgrounds and enterprise demands, and adopt different work-study combination modes. For financial type of higher vocational colleges, they can actively explore order cultivation, work-study alternation, post practice, service outsourcing and other modes, apply modernized education technology concept, and cultivate students' post professional capacity. For engineering type of colleges, they can explore modernized apprenticeship system, the processing of material provided by foreign clients, joint enterprise running and other modes to conduct work-study combination. The key is to present their own characteristics as per their respective specialty characteristics [8]. 


\section{Deepen Mixed Teaching Reform, and Actively Adapt to New situation}

Establish working process oriented course system. Higher vocational colleges should set course systems, reconstruct course contents, cultivate professional skill-type talents that are in urgent demand for regional economy, and serve for the regional economic development as per the industrial and enterprise production procedures and professional post requirements. Firstly, investigate and analyze the demand of processional capacity, post skills and knowledge for the industry and enterprise post (group) related to the specialty, confirm the professional capacity, working process and knowledge under typical working scene, and typical profession. Secondly, under the guidance of industry-enterprise-school cooperation council, define the corresponding capacity, skill and knowledge objective that should be reached in professional course teaching, and then set course system on this basis. Thirdly, based on the working process, confirm typical working task, and adopt task-driven mode to reconstruct knowledge point. Fourthly, formulate the course standard and course teaching standard, and meanwhile, conduct online course development, compile school-based teaching textbook, and establish resource library. In the course system construction of higher vocational colleges, it is requested to reinforce the cultivation of professional capacity, attitude and comprehensive quality, meet practical, opening and professional requirements, implement professional standards, occupational standard and post standard, and handle well the relationship of quality, knowledge, capacity and skill.

Schools and enterprises jointly develop courses. Enterprises should conduct post training for employees, and higher vocational colleges should cultivate students' professional capacity, both the schools and enterprises should jointly develop courses that can meet their demands, and the contents should involve enterprise culture, professional ethics, project management, business procedure, single skill training, etc. Enterprise personnel should teach lessons, and the students can also accept capacity and skill training in actual professional atmosphere through post practice or network online courses.

\section{Introduce Talents, and Promote the Construction of Double-qualified Teacher Groups}

The promotion of double-qualified teacher group construction is the important factor for implementing workstudy combination mixed teaching. Only teachers with professional theoretical knowledge and higher practical skill level can cultivate high-qualified skill-type and applicationtype talents through utilizing mixed teaching.

The government should reinforce macro policy support, and implement tax reduction and exemption for enterprises participating in work-study combination, and then normalize part-time teacher qualification of higher vocational colleges, part-time teacher employment and evaluation, part-time teacher training and other procedures through the mode of legislation, ensure the rights and interests of part-time teachers, and mobilize the enthusiasm for enterprises to participate in workstudy combination.
School-enterprise cooperation, expanding externally employed teacher channel. Higher vocational colleges should conduct well the long-term plan of part-time teacher group construction, carry out multidirectional cooperation with enterprises, jointly construct training base, hire skillful craftsmen, technical experts and business backbones of enterprises, drive service outsourcing projects, the outstanding persons in the previous graduates, and other channels to expand part-time teachers, and increase the cultivation input of parttime teachers.

Systematically train the teacher groups of schools. Put forward defined requirements for the cultivation and introduction of teachers in practical operation, mixed teaching and other new teaching concepts and methods. Utilize offcampus training base, annually assign teachers for post training, so as to improve the mixed teaching level and practice capacity of teachers.

Hold or encourage teachers to participate in various forms of professional skill competitions. Through holding professional skill competitions or encouraging teachers to participate in professional skill competition, implement the concept of "using competition to promote education", help teachers to understand the education concepts and methods of the peers, timely update their own concepts, knowledge and capacity structure, and promote the implementation of workstudy combination mixed teaching.

\section{E. Create Innovation and Entrepreneurship Platform, and Build Productive Practical Teaching Base}

Construct innovation and entrepreneurship education platform. "Mass entrepreneurship and innovation" is now gradually penetrated into the student cultivation process for higher vocational colleges, and carries out the innovation and entrepreneurship education oriented to all students, adheres to emphasizing on practical experience, sets foot on sustainable development principle, awakens the innovation and entrepreneurship spirit of higher vocational college students, and improves high-end skill type talent cultivation quality. It is requested to build course teaching, practice experience, quality expansion "three-in-one" innovation and entrepreneurship education platform.

Schools and enterprises implement in-depth cooperation, and build productive training base. The on-campus training base constructed in higher vocational colleges can attract the participation of enterprises, the in-depth cooperation of schools and enterprises, and the construction of productive practical teaching base, i.e., the enterprise production base (or operation service place), with professional skill training function in the meantime, and it can meet the students' skill cultivation, the scientific research of teachers, and the enterprise production (service) application requirements.

Vocational colleges, teachers and enterprises jointly prepare to build enterprises engaged in technical development and technical service. Schools will be responsible for preparing the site, teachers will utilize their own professional knowledge, scientific research capacity and human resources, while enterprises will be responsible for the investment in capital; teachers will guide students to complete true enterprise projects, 
and then provide "work-study combination" practical training platform through relying on specialties to create enterprises, and assuming sole responsibilities for the profits or losses.

Improve the simulation degree of on-campus training base. The on-campus training base should have true or stimulated professional environment, with theoretical teaching and practical capacity cultivation being closely combined, explore the scientific research, and service function of on-campus training base, utilize computer technologies, and virtual reality to conduct the construction of stimulated training base, and construct the on-campus training base integrating training, production, service and skill training.

\section{F. System Innovation, Ensuring the Work-study Combination Mixed Teaching}

Under the government-industry-enterprise-school cooperation council, build work-study combination mixed teaching center, coordinate the work-study combination mixed teaching reform and implementation, formulate the work-study combination mixed teaching management operation mechanism, teaching quality monitoring mechanism, and educational system and credit flexibility mechanism, etc.

Build credit bank center. Industrial theoretical study, enterprise practice and training, online website learning and other diversified learning modes and diversified course designs need to communicate with enterprises and the school through the credit bank center, and let students autonomously and flexibly select learning modes.

Build work-study combination mixed learning quality evaluation system. Enterprise personnel, teachers and students should constitute the evaluation subject, take the professional post (group) capacity and industrial professional qualification standard as the basis, and build the quality evaluation system taking professional capacity, professional quality, innovation capacity, etc. as the main evaluation contents, and involving process and development.

Build professional teacher practice and exercise motivation mechanism as well as scientific teacher professional capacity evaluation system, and encourage teachers to utilize spare time to participate in actual practice, and this will be regarded as the important reference for annual evaluation, appraisal and title promotion.

\section{CONCLUSION}

Vocational colleges are now exploring "work-study combination" talent cultivation mode; under the collision of MOOC and other internet+ thoughts, through referring to the vocational education concepts in Germany and America, higher vocational colleges should strive to explore work-study combination mixed teaching mode with characteristics, and promote the connotation development of the school at "postdemonstration" and "post-backbone" time.

\section{REFERENCES}

[1] Jia Shengchao, and Zhang Xinke. The Design of "Work-study Combination" Teaching Mode System Design Based on German Experience [J]. Higher Agricultural Education, 2014, 1: 119-123.

[2] He Xingyu, Cao Keguang, and Wang Hui. Hundred-year Inheritance and Development of "Work-study Combination" Vocational Education Thought [J]. Chinese Vocational and Technical Education, 2015(19): 70-73.

[3] Sun Yan. Existing Problems and Solution Thought for the Work-study Combination Cultivation Mode of Higher Vocational Colleges [J]. Modern Education Management, 2013(5): 69-72.

[4] Yang Lilian, and Liu Xiaomei. Teaching System Connotation Analysis and Operation Research on the Work-study Combination Teaching System of Higher Vocational Colleges [J]. Vocational \& Technical Education Forum, 2013(30): 4-7.

[5] Li Xiaolong, Zhang Chenrui, Geng Bin, and Guo Yong. Mixed Teaching Mode Reform of Higher Vocational Colleges: "MOOCs Era" Exploration and Enlightenment [J]. E-education Research, 2015, 12: 5255.

[6] Liu Hua. Online Courses Integrate in the College Course Teaching System: Obstacles and Breakthroughs [J]. Studies in Higher Education, 2016, 5(37): 68-72.

[7] Du Shujuan. Discussion about the Implementation of Mixed Teaching in Higher Vocational Colleges [J]. Education and Vocation, 2011, 5 (14): 83-84.

[8] Han Qisheng. Discussion about "Work-study Combination" Talent Cultivation Mode in Higher Vocational Colleges Taking Shenzhen Polytechnic as an Example [J]. Education and Vocation, 2011, 4 (12): 25-26. 